ISSN: $2594-4827$

\title{
EDUCAÇÃO INFORMAL, MUSEU HISTÓRICO NACIONAL E ZOOLÓGICO: O RELATO DE UMA PROFESSORA DA FORMAÇÃO PROFISSIONAL
}

\author{
Maylta Brandão dos Anjos ${ }^{1}$
}

\section{RESUMO}

Este artigo trata de um relato, cujo objetivo foi levantar uma reflexão sobre a educação informal acontecida no Museu Histórico Nacional e no Zoológico do Rio de Janeiro. Parte da experiência de uma professora da formação profissional que vê, no contexto atual, a importância de registrar um momento acontecido no Museu, espaço que foi e ainda é, apesar do recente incêndio que sofreu, guardador de nosso capital histórico e de nossas memórias ancestrais. $\mathrm{O}$ que temos aqui se traduz nas dimensões de um processo humanizado que envolve as questões sociais, políticas, culturais, profissionais e territoriais. Evoca a educação informal colocada numa abordagem mais ampla de conhecimento, e ressalta o campo de construção, conceituações e disputa onde ela se situa. A escolha metodológica por um relato se deu por esse permitir diferentes contornos de exposição e análise, colocando, em crédito, a via formadora de laços afetivos e afetuosos, num processo de narrativa que se pretenda laica e democrática. Dessa forma, o relato apresenta uma prática profissional, exercida na docência, como aporte agregador das relações humanas. Enfatiza a importância da existência de espaços abertos e não excludentes para o acesso de todos que queiram visitar, em estudo e lazer, o que foi organizado como acervo do conhecimento formativo da sociedade. Portanto, este trabalho põe em cena algumas definições e pensamentos que tem o ensino e a ciência como protagonistas de um aprendizado que se coaduna ao prazer das descobertas e ao fortalecimento dos vínculos humanos acontecidos na informalidade da construção do saber. Traz uma experiência concreta de quem quis lecionar com quem quis aprender. Ao findar, a proposta que envolveu a análise foi a de contribuir às diferentes alternativas e desenhos em que a educação informal possa acontecer, ampliando sua ação nas possíveisvertentes da formação profissional.

Palavras-chave: Educação informal; Relato de experiências; Aprendizagem.

\begin{abstract}
This article is about an account, whose objective was to raise a reflection on the informal education that took place in the National History Museum and in the Rio de Janeiro Zoo. At a time when the Museum has gone ablaze and lies in ashes, an account that presents it as a setting constitutes yet another memory of this great and important space that was and still is the keeper of our stories. What we have here translates into an experience that has an impact on the humanized process that involves social, political,
\end{abstract}

\footnotetext{
${ }^{1}$ Professora e Pesquisadora no Programa de Pós-Graduaçãoem Ensino de Ciências, PROPEC/Instituto Federal de Educação, Ciência e Tecnologia do Rio de Janeiro(IFRJ). E-mail: maylta.anjos@ifrj.edu.br; (https://orcid.org/0000-0001-6272-5056)
} 
cultural, professional and territorial issues. It evokes informal education in a broader approach to knowledge, and highlights the field of construction, conceptualizations and dispute where it lies. The methodological choice for an account was to allow different contours of exposure and analysis, placing, in credit, the way of forming affective and affectionate bonds, in a process of narrative that is intended to be secular and democratic. Thus, the report presents a professional practice, practiced in teaching, as an aggregating contribution of human relations. It emphasizes the importance of the existence of open and non-exclusive spaces for the access of all who want to visit, in study and leisure, what was organized as a formative memory of society. Therefore, this work brings to the fore some definitions and thoughts that have teaching and science as protagonists of a learning that is in line with the pleasure of the discoveries and the strengthening of the human connections happened in the informality of the construction of the knowledge. It brings a concrete experience of who wanted to teach with whom he wanted to learn. At the end, the proposal that involved the analysis was to contribute to the different alternatives and designs in which informal education can happen, expanding its action in the possible slopes.

Keywords: Informal education; Reporting of experiences; Learning.

\section{INTRODUÇÃO}

O artigo trata de um estudo, tipo relato de experiência, elaborado no contexto de uma atividade de extensão em Museu e Zoológico da cidade do Rio de Janeiro. Permitam-me a primeira pessoa. Começo, então, indagando o que entendemos por educação informal.

Ao questionar sobre esse assunto, me veio uma inquietação do que pudesse aproximar e distanciar dois conceitos como ensino e humanização. Logo, de forma didática, busquei definir, a partir de várias inspirações que estarão descritas ao longo desse artigo, como FREIRE, 2005; GOHN, 2011; JOSSO, 2004; LIBÂNEO, 2010; MARANDINO et al, 2011; SANTOS, 2002; entre outros, pensam educação informal EI - ou o que perpassa por ela. Alguns pontos, na confluência do olhar lançado pelos autores, assinalaram que a EI começa a definir seu campo, ou seja, ela se constitui numa tentativa educacional mais aberta; espontânea; inclusiva, afetuosa, democrática, emancipatória e cidadã. Corresponde a um aspecto menos protocolar, a um feitiodialógico e assistemático, e por não ser tutelada por leis e diretrizes, normalmente, ocorre nas conversas, nas contações, nos diálogos, nas exposições de eventos culturais e científicos; nas peças teatrais; acontece nas redes sociais; nos museus; jardins; atividades culturais e acadêmicas; nas vivências com todos os sujeitos possíveis, entre 
eles familiares, amigos, vizinhos; e aqui trago para a cena o interlocutor ocasional, o que representei ser num fortuito encontro em que a EI foi a tônica.

A EI pode acontecer, também, na perspectiva do auxílio à compreensão dos fenômenos sociais e naturais, ou como aporte de outras atividades complementares aos saberes constitutivos da formação humana. Ainda que essa definição esteja em franco desenvolvimento, sobre ela há uma relação mais larga e livre que permite o episódio de dois ou mais sujeitos se encontrarem com objetivo de aprofundar e dá significado e luz aos seus saberes, proporcionando mais interatividadee integração entre os participantes dessa ação. Acontece em qualquer espaço e de forma "desfilada" às tantas diretrizes e regimentos que "engessam" em formato os processos em que a educação possa acontecer.

A materialização da EI se dá sob vários contornos e situações, tem na concepção criativa e nos espaços alternativos um novo fazer que vai além das práticas educativas comumente pensadas e dos lugares frequentados pelos cidadãos como espaços de formação. Ela é capaz de fortalecer ações e influências no campo do conhecimento e atuação desse, considerada dialética em sua essência. Para Libâneo (2010, p. 31),

A educação informal corresponderia "a ações e influências exercidas pelo meio, pelo ambiente sociocultural, dos quais resultam conhecimentos, experiências, práticas, mas que não estão ligadas especificamente a uma instituição, nem são intencionais e organizadas.

Tendo em vista a narrativa exposta, o objetivo desse relato não se limitou a registrar uma experiência apenas, mas pretendeu, sobretudo, trabalhar a produção do conhecimento que se dá nas distintas áreas vivenciadas pela educadora, em um compartilhar de descobertas e dados, na interação e conexão de uma prática que leva em conta o conhecimento que a sociedade criou e ressignificou ao longo de sua existência. Conhecimento em que se invoca coerência histórica e que caminha em pista contrária à alienação social, buscando como meta a construção do pensamento crítico de sociedade e a participação fincada em princípios de alteridade e igualdade.

Por incorporar dimensões do casual e do empírico, os saberes apresentados por via da EI, a um quarteto de crianças que estavam circunscritas pela ausência de seus 
pais e afetos, me fez incorporar no texto que se lê aqui em pesquisa, uma narrativa acadêmica de vivências do apreendido, para que de modo espontâneo e assistemático, apresentasse aos meninos os fatos e fenômenos, a história e a geografia, a gramática e a matemática, interligando o ali revelado ao que experimentávamos - eu e os quatro garotos filhos da rejeição. Minha tentativa foi de apontar significados amplos, flexíveis e abrangentes na EI trabalhada com eles, interliga-la ao campo da educação, nos seus distintos temas, apresentar e viver o conhecimento para o aprofundamento das coisas do mundo, para a desalienação ou rompimento com a ignorância retórica.

Finalmente, o artigo teve na aproximação do diálogo que aconteceu frente a uma experiência na educação informal no Museu Histórico Nacional e no Zoológico do Rio de Janeiro o seu pressuposto. Para tanto, me conduziu nesse caminhar o seguinte questionamento: qual o lugar da educação informal no contexto da prática docente, para a formação de cidadãos considerados proscritos sociais, ou melhor, na condição de vulnerabilidade social? Arrisco refletir e colocar em análise essa questão que perpassa as várias vertentes do ensino, destacando tal reflexão como fortalecimento de análises no processo de humanização na díade ensino e aprendizagem.

\title{
POR QUE A EDUCAÇÃO INFORMAL?
}

Se formos aos dicionários diversos, encontraremos definições bem parecidas do que seja educação informal, a descrita abaixo é representativa para o que, nesse artigo se pautou como tema. Avalio ser esse o primeiro passo de compreensão do objeto de estudo, assim:

\begin{abstract}
A Educação Informal é o processo pelo qual durante toda a vida as pessoas adquirem e acumulam conhecimentos através das suas experiências diárias e da sua relação com o meio. Está relacionada com um processo "livre" (não-institucionalizado) de certos saberes, tais como as tradições culturais e os comportamentos característicos das diversas comunidades presentes em cada sociedade...(WIKIPÉDIA)
\end{abstract}

Por ser a EI livre e diária ela cria novas oportunidades e, no calor da hora, aciona o repertório não previsto e pensado entre os sujeitos que partilharam dela. Foi bem isso que aconteceu no relato que será exposto mais adiante. Em decorrência de 
acontecimentos estabelecidos no inesperado dos encontrose na tentativa de trazer elementos teóricos para se pensar esse objeto de análise, o artigo primou pela dimensão do informal se compondo num universo mais alargado de ensino e ciência, que privilegia situações de aprendizagem em espaços de museus e zoológicos, ditos espaços não-formais de ensino, onde o conhecimento acontece de forma complementar à construção de saberes fortalecedores e evidenciados nas ações mais prazerosas e significativas de descobertas, articulações cognitivas e exemplificações da história constituída pela sociedade.

Paralelo a isso, soma-se à resposta do "por que a EI", o motivo de ela ser um recurso a mais, com estímulos à curiosidade que move os sujeitos. Tem como primeiro elemento o aspecto da naturalidade, não possuindo uma diretriz formal ou condutora, mas sim um texto que passa a ser construído pelos sujeitos que observam nas cenas, o propósito dos espaços divulgadores da ciência e cultura com os saberes ali ofertados. Começam a perceber a lógica conferida à organização, segundo as intenções desses espaços. Por isso, lançar mão às várias formas de aprendizado que se complementam pode conferir melhor e maior formação aos sujeitos que tem nos museus, zoológicos, parques naturais, teatros abertos e contações de histórias, novos aportes ou recursos para pensar o mundo, para pensar os fenômenos naturais, sociais e culturais produzidos nele e por ele. Portanto, a EI forma-se, também, de espaços outros, onde sejam trabalhados temas que envolvam elementos dos elementos científicos e culturais.

Destarte, ao tentar responder a pergunta em epígrafe, tenho claro a educação informal como propositiva de atos que tem como agentes educadores os diferentes grupos sociais, e como a narrativa parte de um caso e público acidental, ela se coaduna com o que se expressa na família, nas conversas com os amigos, na relação com a vizinhança, nos encontros com colegas, nas reuniões e atividades das instituições religiosas, na programação televisiva, no programa de rádio, nas redes sociais, nos clubes, nos transportes coletivos ou individualizados e nos demais espaços de ocorrência dos diálogos, papos, trocas de ideias e onde haja pessoas interagindo.

No caso das exposições - vistas pelos nossos sujeitos do relato no museu e no zoológico, palcos das visitas acontecidas-, oportunizaram pensar a ciência, a natureza, a diversidade da fauna, a arte e a cultura sob uma nova dimensão que facilitou o processamento das informações, se constituindo na arena que deflagra e faz acontecer a 
EI. Foi no imprevisto de uma atividade de extensão universitária e na espontaneidade acontecida no dia-a-dia que a educação informal pode ocorrer no sentido de lapidar, cada vez mais, o olhar de imaginação e criatividade, não somente dessa pesquisadora, mas de quatro meninos em estado de vulnerabilidade. Esses buscaram saber mais sobre as produções e características do desenvolvimento da sociedade e da sua humanidade, quiseram saber sobre sua heterogeneidade e, observaram que os laços afetuosos são estabelecidos numa ordem mais livre e intuitiva entre aqueles que buscam prazer nos sentidos da aprendizagem. Tal fato deu maior sentido àminha prática docente.

O passear histórico nos leva a crer que o processo de formação dos sujeitos antecede, e muito, a instituição da educação formal, faz ver que na informalidade o saber se complementa. Entretanto, no tempo atual, o processo de aprendizagem passou a ser associado somente a escola, a instrução convencional, ao espaço formal, a formalidade legal; e isso por quê? Essa foi outra inquietação que gerou mais uma pergunta condutora me mostrando, em pesquisa, a importância dos espaços informais de ensino, e partisse à defesa da EI, pensando a sensibilidade do ato de educar, as especificidades do saber e oaguçamento da consciência na análise das situações,cujo sentido torna-se real, necessário e vívido para aqueles tantos que querem compreender as coisas do mundo.

$\mathrm{Na}$ intimidade das palavras colocadas num relato de vivência, e na expectativa que elas pudessem ser expostas como registro de mais uma prática docente, aventuro a traçar um diálogo acerca de mostrar singularidades em ações, sentires e sentidos que vão se dando em campos, sujeitos e objetivos diferentes. Somos aqueles que não se "despregam" do que nos formou como ser e amante do conhecimento. Aqueles que têm claro que as experiências relatadas nos sensibilizam, provocando outros estares e olhares que ampliam e provocam novos combates. A palavra é mola motriz do mundo, do nosso ato profissional. Acredito ser ela o elemento mais revolucionário quando atinge poros e ideias. A palavra investida em saber dá formas aos sentidos e à vida. Por isso esse é um dos porquês que me conduz a essa escrita, cujo escopo é nos levar a pensar a EI, as circunstâncias e as situações que colocam em evidência o que se tem feito, para além do chão da escola e dos limites dela, dentro das possibilidades descortinadas à nossa frente num compêndio em que a democracia é resgatada no sentido da liberdade que a tonifica. (SANTOS, 2002) 
A educação é viés de variáveis diversas. Portanto, em decorrência disso, o que está em debate é um modo outro de fazer educação; de colocá-la para além de um conceito, de um costume, de uma definição, de uma abordagem, ou mesmo de uma narrativa. Ela é caleidoscópio de formas e cores, de junções e vários sabores. Ela segue uma rítmica de novas composições e caráter. De objetos diversos que compõe olhares. Resgata a história de nós, reorganiza períodos e tempos. Dá verdade e lucidez à produção da humanidade e a sua existência.

Assim, de forma mais aberta e de maior relação, num modo de cooperação dos pensamentos e de suas demandas no campo da consolidação de laços afetivos, o ensino, também, vai se dando por via da necessidade e encantamento do saber, que se apresenta pelas respostas ou perguntas acerca das trajetórias traçadas pela sociedade.

Busco aqui não me limitar somente à experiência particular, a qual transformo numa narrativa pontual; coloco os escritos como um exercício de memória e leitura que me assumiu no contorno da vida e da identidade docente, como singularidade de uma pesquisadora que ativa suas emoções, reavivando um momento de inteireza da profissão. Trago uma experiência que possa servir aos colegas que participam desse mesmo sentido e sensação na prática que assumo. Me reinvento no espaço informal, com a vontade exposta de aprendente, no devir de uma observadora de si que se refaz no própriodo saber. Na escrita e na leitura de uma cena me localizo em reflexão, em análise e em busca teórica, que dê conta do ato escolar, aquele que se faz no objetivo de integrar o fazer da vida às surpresas que ela apronta.

Por entender que a dimensão educacional transcende o espaço escolar, sobretudo quanto à formação irrestrita, cidadã, crítica, profissional e humana, e no abrigo à pergunta "por que educação informal", respondo: porque ela se dá naespontaneidade das relações humanas, na complementaridade dos saberes, na independência, na informalidade dos lugares, na perspectiva de trocas dos fazeres, na ativação do conhecimento, no estímuloà imaginação, na concretude da cultura,na abstração da arte, na configuração do pensamento lógico e nas compreensões léxicas da vida. A defesa por ela é razão que me assume no objetivo de desmistificação e popularização da ciência, na democratização e humanização do saber, de torná-la acessível e real aos nossos tantos meninos e meninas que estimulados poderão reescrever uma nova história com trajetórias de superação. Defendo a EI por considerá-la uma síntese de elementos que 
tratam, retratam e se mostram numa visibilidade imaginativa, tornando possível as relações entre perspectiva, desejo, formas e o concreto dos saberes.

O processo formador da EI extrapola as regras e os limites ritualísticos que regem a educação formal. E isso foi provado e vivido pela pesquisadora numa tarde de domingo, nos ditos espaços informais de educação. Tal experiência se deu de forma inata, o sentido de aprender significou, naquele momento, descobrir intuitivamente o que já se sabia com ricas humanizações. A troca acontecida, naquele território ímpar, foi ato que sobrepujou a formalidade educacional. Assim, a experiência situou a ação de educar livremente num dos papéis mais fulcrais da criação docente.

O exercício da prática docente me fez elaborar, de forma legítima, o aprendizado nas suas várias simbologias e significados, perpassando pelas brechas e falhas de políticas educacionais que colocam um público à deriva, localizando-o à margem da construção do saber formal.

No relato exposto como ponto de análise e registro dessa pesquisa, ficou a sensação vívidade nos distanciarmos do ensino e de suas significações mais relevantes quando preconceitos e segregações são maiores que a nossa humanidade e nossa capacidade de refletir o mundo como seres iguais que somos.

Josso (2004) nos atende nessa análise ao nos despertar o olhar sobre a formação centrada nas dimensões experienciais das quais se forma novas identidades requerentes de compreensões mais profundas, de reflexões das vivências significativas e das situações e acontecimentos do ensino.

O "pensar sobre as experiências" se rompe na busca de nós mesmos, e pensar a EI é, também, partir para a busca de conhecimento e do auto-sentido. São esses que provocam o desenvolvimento da criatividade, da capacidade de avaliação, da relação de ensino, dos suportes imaginários que destacam situações reais contadas, tendo como fio condutor uma narrativa apropriada ao tom que se quer conferir ao objeto investigado, tornando o professor o ator principal de uma observação (JOSSO, 2004).

A EI não se fecha ao mundo, ao novo, ao inesperado e ao diferente. Não pode deixar que desfile em sua frente uma ordem de exclusão que retifica o outro na sua condição de sujeito de ação. Que reifica ao invés de humanizar. No intuito de desempenhar seu papel de transformadora, produtora de conhecimentos e de novas atitudes elaextrapola o ato de agir dentro da formalidade legislativa e lacunar, e deixa 
claro que precisa estabelecer diálogos com a realidade na qual está mergulhada. Ativar os conhecimentos e encharcar-se de possibilidades e caminhos de inclusão é o que lhe cabe. Esses devem ser seus alvos dialéticos dessa proposta.

O caminho de discussão acerca da EI, encontra em Gohn (2011) um argumento que foca as experiências compartilhadas de forma coletiva, levando a considerar o diaa-dia de nossas ações como importante contribuição. O cotidiano fica demarcado no ato de participar e de aprender de forma leve e aberta a EI, porque ao agir em ambientes naturais, o suporte maior se faz nos contatos, nas relações sociais, culturais, educativas e docentes que se desenvolvem no objetivo de viver as oportunidades, a ludicidade, os novos ambientes oferecidos aos distintos gostos, as distintaspreferencias e escolhas. Soma-se a isso o sentido de pertencimento ao local onde se aprende que desenvolve o empoderamento dos sujeitos.

Ainda em Gohn, podemos inferir que a educação informal possui contornos diferenciados, e há que ter claro a sua importância no mesmo nível na educação acontecida nos espaços formais e não formais de ensino. Nela os primeiros contatos são demarcatórios de saberes que se levarão ao longo prazo da vida. Dessa forma, pais, parentes e responsáveis pelas crianças passam a ser os mediadores iniciais do conhecimento das coisas.

Segundo Libâneo (2010), ao explorar espaços para além dos escolares a EI, amplia o ato docente, situando outros elementos que se dão em atividades e experiências diversas na demanda escolar. Aportes da cidadania são aí reconhecidos como possibilidades de novas percepções e realização de uma compreensão mais fina do contexto cotidiano. Qualquer atitude com essa intenção pode virar aula fresca, no frescor das delícias que é ensinar e aprender. Afirma, ainda o autor que para aprender e para ensinar qualquer espaço pode servir de livro de descobertas cujo sentido seja o amplo conceito da liberdade. No autor,

(...) não há uma forma única nem um único modelo de educação; a escola não é o único lugar em que ela acontece e talvez nem seja o melhor; o ensino escolar não é a única prática, e o professor profissional não é seu único praticante (LIBÂNEO, 2010, p. 26). 
Se a EI pode acontecer em diferentes territórios, locais, formas, com diferentes aproximações e nas diversas intenções, as suas ações permeiam e modificam modo de vida, cultura, ambiente, profissão, técnicas e tecnologia. Reconstróinovos sentidos e perfaz um mundo sociopolítico de novas práticas e contatos. Na sequência das análises ela é exercida pelo meio, pelo ambiente sociocultural e educacional que se desenvolve nas relações dos sujeitos com seus grupos sociais, com os coletivos que vivenciam e da forma em que vivenciam. Assim, acontece no

(...) ambiente humano, social, ecológico, físico e cultural, das quais resultam conhecimentos, experiências, práticas, mas que não estão ligadas especificamente a uma instituição, nem são intencionais e organizadas (LIBÂNEO, 2010, p. 31).

Ao pensar a pergunta do "por que a EI", me apoio na leitura de Chassot (2000), e destaco como motivo docente ela poder acentuar em práticas que buscam romper o analfabetismo científico, em traços fortes, numa política de humanização e voluntariado, os dados da realidade que expandem o fazer. Por isso, aprofundar estudos sobre tal fato, nos remete à ampliação do sentido de educação e de formação que envolve maior e melhor atuação dos atores sociais nas trocas de saberes.

Em Freire (2005), a prática democrática, e no caso específico do nosso objeto de estudo, a EI para além de possuir a finalidade de identificar, caracterizar e partilhar ações que potencializam e empoderam os sujeitos participantes de uma intenção formativa, ela pode conferir, em qualidade, o conhecimento produzido no afeto, a compreensão do mundo como viés emancipatório naqueles que compartilham da vida social.

Por ser composta de circunstâncias históricas, segundo Ghon (2011) a EI acontece de forma espontânea, instintiva e natural, atendendo a leigos, a alunos, a profissionais docentes, entre outros sujeitos, naquilo que possuem curiosidade de saber. Dessa forma, também opera nas práticas sociais, nas experiências e vivências, favorecendo a produção de conhecimentos. Ainda na autora, podemos afirmar que se anuncia e se articula ao universo de saberes disponíveis, passados, futuros e presentes, no esforço de pensar/elaborar/reelaborar sobre a realidade em que os sujeitos vivem, aflorando as emoções que partilham na curiosidade de se compreenderem em histórias. 
De tal modo, no "percurso metodológico de um relato de experiência", ponho em evidência os vários tons vividosna EI durante um breve encontro que se tornou marcante em minha prática docente. Pude, enfim, criar mais alteridade no inesperado, na poesia em que se pode apresentar e viver a ciência, a profissão e a formação constante. Portanto, o conhecimento, a interação e a análise foram categorias vivenciados na EI no seu tom maior. Essas categorias de ação expandiram relacionamentos, redirecionaram meu fazer docente, fazendo sentir que a ciência é viva, como são vivos os sujeitos que dela participam.

A EI se apresentou como mais um benefício essencial para a vida, proporcionando outra visualidade que apresentou novos aspectos. Aprofundouo senso imaginativa dos sujeitos sociais por estar entre o lugar que traz a escola para outros espaços mais leves e possíveis de se trabalhar o saber no amplo diálogo.

Finalizando, a indagação inicial feita por mim é assim respondida: por que dou vida a um relato que tem na EI seu maior aporte. Porque a EI é traço que demarca a minha existência como profissional e caminha no sentido de dar luz a outras estradas. Porque o por meio de um relato tratode registrar, numa narrativa mais próxima, acontecimentos que descreverão e explanarão determinado assunto de interesse coletivo ou individual na EI. Porque primar pela EI se constitui num guia metodológico de novas abordagens nas práticas docentes. Porque pode enfatizar situações que são essenciais para o desenvolvimento de um ocorrido. Desta formaa EI, transcrita no relato pessoal, me vestiu como percurso metodológico que será posto a seguir

\section{PERCURSO METODOLÓGICO DE UM RELATO DE EXPERIÊNCIA}

O percurso metodológico se constitui de uma descrição cuja sistemática é voltada à abordagem qualitativa, de escrita livre e do tipo relato de experiência, realizada em uma atividade de extensão/divulgação científicaacontecida na cidade do Rio de Janeiro, em novembro de 2017. O relato foi baseado na experiência da professora/pesquisadora, nessa atividade acadêmica, que traz elementos de vivência da educação informal.

O cenário do relato apontou para o desenvolvimento de uma metodologia que, em sua característica maior, necessita ser experimentada e vivenciada numa biografia 
que coadune elementos e variáveis de análise. Por conseguinte, nessa metodologia a narrativa apresenta a cena, o cenário, os sujeitos, o contexto e o acontecimento que se designam no objeto de análise, metodicamente narrado nas atividades realizadas, na espontaneidade e naturalidade que deram o tom discricionário à pesquisa.

Assim, esse relato de experiência apresenta um texto colocado em sua integralidade que proporciona uma contribuição reflexiva para área de atuação profissional docente e o faz por via de uma educação informal que se pretende humanitária. Esse fato traz os pontos da metodologia para as ações tomadas na situação em que as impressões da vivência são feitas de modo contextualizado com o aporte teórico que alimenta a análise e a prática pedagógica no relato colocada. Dessa forma, o relato não pretende ser uma narração emotiva e subjetiva da autora, muito embora, em alguns pontos essa emoção possa ficar à flor da pele e acontecer, também não se destina a ser uma divagação pessoal e aleatória, muito pelo contrário.Destina-se a ser elemento e registro de uma ação que envolve nossa capacidade de ensino e responsabilidade cidadã, perpassando o saber nos espaços da educação informal, dedicados ao ensino e à construção de uma memória ligada à ciência.

Essa metodologia se encontra num campo queconfere maior liberdade na descrição das impressões e das linguagens pessoais dos sujeitos pesquisadores, sem que se distancie de um trabalho científico. Nesse interim é o tom dos relatos de experiência, que remeter-se-á a essas considerações. Logo, esses devem ser representativos e significativos para a área de estudos em questão, e nesse caso, para repensar espaços, situações e formulações de saberes na prática da educação informal que estabelece as ponderações e reflexões sobre o objeto pensado nesse tipo de prática docente, fincada na experiência e no seu aparato teórico. Os relatos contribuem para pesquisas ao ampliar o efeito da experiência como potencial estudo dessas vivências na prática profissional e na formação docente.

O marco teórico de referência se localiza na ação e na educação que considera o ato de ensinar como objetivo e objeto dessa breve vivência, apropriando-se da metodologia em que a descrição do contexto e as inferências são tecidas a partir do que nos modifica, mexe e nos leva a refletir, em batalhas, o que nos inquieta na ação educadora. Por isso, eis aqui construído em letras, palavras, frases, sentimentos e críticasorelato de experiência mobilizado a fazer-nos pensar a educação de descobertas. 


\section{O RELATO}

No dia 12 de novembro de 2107, representando minha instituição de ensino que tem aporte na formação profissional, estive presente no II Festival Interuniversitário Cultural do Rio de Janeiro, realizado na Quinta da Boa Vista, organizando a contação de histórias infantis. Além de histórias, muitas surpresas me foram reservadas para esse dia. A maior delas me aguardava ao visitar o Museu Histórico Nacional, uma das mais antigas instituições científicas de nossa história natural e antropológica, que nesse dia estava aberto à visitação gratuita. Lá quatro meninos ávidos para verem as múmias, os esqueletos de dinossauros, as coleções de insetos e artefatos indígenas, imploravam ao porteiro/vigia para entrarem, ao que esse negava peremptoriamente. Ali estava presente o caráter elitista, seletivo, de obediência cega que se acentua no não reconhecimento de si, e destaca-se na subserviência do pequeno poder. Caráter e característica que revelam o tom preconceituoso que preserva a "aristocracia" do que ela mesma cria. Intervi nessa recusa, que a mim além da compreensão histórica que ali representava, pareceu estar também impressa a nossa capacidade de sermos cruéis. Logo de cara, já na entrada, atingida por um misto de revolta pela situação já dada e afeto pelos meninos, me responsabilizei, firmemente, pelas crianças que mostravam seus olhares estampados em desejos àquela que poderia os ajudar. Reconhecendo-me como sua tutora, me acompanharam com sua alegria infantil e numa inocência já gasta, vivida no amargor de suas vidas. Começamos ali uma aliança que se afinaria e marcaria meu dia, minha história e minha ação como professora, que não deixa de sê-lo onde quer que eu esteja e em qualquer situação que esteja. Surpresa, incredulidade e dúvidas de existência real do que viram, ficavam expressas em suas perguntas e olhares que se dava a cada sala, a cada exposição que lhes apontava. Pacientemente e amorosamente nossa relação ia se estabelecendo. A cada explicação da história das mumificações, empalhamentos, taxidermia, conservação $e$ preservação dos esqueletos, eles diziam: - "tia, não acredito que essa múmia já foi gente (...), que essa passarada já foi de verdade!!". Mas estavam mais que curiosos para ver tudo e tudo saber. Queriam descontar o tempo nos desejos. Apreciavam a beleza dos móveis coloniais, dos quadros históricos, como ninguém. Com pressa de verem todos os salões à tempo de fazerem outra atividade, preocupados perguntavam: - "E o zoológico, tia? Vai levar a gene também? Vai dar tempo? Vamos para lá assim que acabar aqui, não é??!!". Junto àquelas crianças, que furtadas da companhia de seus pais estavam, vi que o mundo há de substituir por via dos seus, o que se falta ao outro; rede de humanos devemos ser. Aporte e conjunto, corpo de sistemas que se interligam, dependem e garante a vida. O outro, extensão de nós, retroalimenta-nos e nos torna mais fortes. Com essas crianças fui mais contadora das histórias, das lendas e da cultura do nosso povo; quiçá tenha sido melhor professora, que no campo da educação informal, na informalidade de ser, com recursos concretos de experimentação, conhecimento e ação praticou o ensinar e aprender na dinamicidade de possibilidades próprias. Ah, tínhamos tudo para o rico aprendizado ser realizado. Articulamos o olhar de curiosidade e gozo do conhecer com quem quis ensinar no ambiente (museu e zoológico) mais propício à demonstração e construção do conhecer, entender, compreender que se dá na troca desse querer. Dia completo e memorável de cultura, ciência, felicidade e arte esse quarteto me proporcionou. Vi assim que as múltiplas formas de conhecimentos são criadas para serem, democraticamente $e$ humanamente vividas sem privilégios para alguns, àquilo que, epistemologicamente, a ciência deveria construiu a bem de todos. E esse mundo, por nossas batalhas, deverá de estar à disponibilidade do conjunto de nossa sociedade, sobretudo daqueles que mais precisam de sua tutela para depois terem perfeitas condições de agirem na igualdade de suas condições. Dessa forma, a ação de plantear e partilhar conhecimento teve na Quinta, a proposta primeira da atividade que fui em coletivo desenvolver, e no Museu Nacional a ação amplificou descobertas 
na convergência daquilo que nos faz igual, cidadãos e dignos de vida. E somos iguais na fisiologia que nos constitui e nos apresenta, somos iguais na fragilidade das coisas e na fortaleza das superações. Somos iguais nas precisões que possuímos e nos tornam humanos; somos iguais em tanto e mais ainda na finitude que somos e que breve, em cada esquina e passo nos aguarda. Em pele sensível, eu e eles, saboreamos nesse dia, aulas simples no imprevisto do acontecido e no contentamento de estarmos no e com o outro nesse feliz encontro. $O$ museu de ares serenos, numa tarde de calmaria, foi nosso deguste socioeducativo, uniu à minha profissão aquilo que sou, que em mim habita como convicção e modo. Em outro campo de ação, dito informal, vivenciei minha prática docente, na liberdade do vento, no encanto do despojamento dos sujeitos escolhidos para comigo naquele lugar estar. Vi que é no outro que buscamos encontrar o eco de receptividade e descoberta que nos torna mais completos, realizados $e$ possíveis como pessoa. Que nos refaz em nós mesmos. O ensino de ciências aconteceu na informalidade dessas ações e o museu funcionou como vínculo histórico e humano de nossas junções. Após a visita às salas do museu, que representavam a lembrança guardada de forma sistematizada e técnica organizada, vi ser apresentada a constitutiva de nossas histórias e culturas. Embebida nesse pensamento, somente uma única fala, dita pelos quatro, num uníssono forte de quem quer viver, me despertou, e ouvi: - "VAMOS AO ZOOLÓGICO!!?" Imperativo ao qual cumpri com o absoluto prazer de minha alma. Para lá nos encaminhamos, $e$ eles corriam na sensação de estarem livres, mas protegidos e tutelados para seu bem. Sabiam e experimentavam ali o valor da autoridade amiga, àquela que a eles é negada. Esses experimentam o revés da proteção que se traduz em autoritarismo, medo e pancada, se não pela violência explícita, ela se dá de forma velada. Assim falavam: - "tia, a gente ficou com medo ali na porta do museu, porque o Nael estava tremendo e achando que iam bater na gente para sair dali, só porque a gente queria ver o dinossauro e a baleia". Nael era o mais novinho, e não sabia porque doía em sua epiderme, de cor negra, o gesto de tanta repulsão. Meus olhos ali lacrimejaram, minha garganta fechou, meus lábios lacraram-se por sermos capazes de tanta segregação e desamor. E partimos, em quinteto de esperança e resistência, olhando o que nos aguardava à frente, como possibilidade de um novo a ser vivido. Ao chegar no zoológico, fui tentar negociar a entrada dos meninos para ver se ela me ficaria mais barata. De imediato, a caixa me disse: - "Desculpa senhora, agora o zoológico é privatizado." O que eu ainda a indaguei acerca da possibilidade dessa visitação conceder, às duas crianças maiores, o preço de meia entrada. Aí ela me disse em alto tom, no que me causou profundo constrangimento: "não dá mais para fazer "caridade". E aí fiquei pensando sobre o que perpassava essa palavra. Ela se retrata a uma política de apartheid maior, onde direitos da maioria são cerceados pelos protetores da casa grande. Os novos "capitães do mato", ressuscitados na ordem "neoliberal", protegiam os donos dos negócios. Para aqueles garotos era negado o conhecer da vida no seu florescer... Na ausência das proteções sociais de um Estado que joga fora os seus, que gasta e exclui cidadãos esses meninos viviam. Mediante a emergência do lucro, o conhecimento vira acesso de grandeza para as dezenas que põe na fagocitose a vida dos milhões que não representam os seus, porque desconhecendo a taxonomia, não se sentem do mesmoreinofilo, classe, ordem, família, gênero e espécie. No setor privado, o maior valor é o do pagamento. É o valor da compra, o do fetiche das mercadorias, das marcas que marcam de sangue a vida dos nossos tantos meninos. "Time is Money and Money is life". E ali isso ficou bem claro, no ato da representativa caixa e do representativo vigia, o que aqui vos falo. Um fato marcou a cena na compra das entradas ao zoológico, os meninos na utilização das estratégias de sobrevivência que possuíam, falaram à caixa, suas idades sociais, as que aparentavam ter e não as que cronologicamente tinham, numa tentativa de fazer-me gastar menos com eles. Mentiram suas idades e incorporam, em si, as "falsas verdades" de si mesmos. Logicamente, de forma didática e afetiva, e entendendo a cena, a fala, o contexto, o cenário e o tom, caminhei na defesa do território desses legítimos, sinalizei que não precisavam, naquele momento, desse artifício. Que estratagemas de mentira nos conduzem sempre ao erro. Que a verdade era sempre soberana; uma aula de ética se fez naquele momento. Refletimos juntos. Calamos, durante alguns 
segundos, para que nossa nova análise, ali então, se fizesse em quinteto; calamos para refletir, no silêncio explicativo, o que nos tomou em surpresa. Entretanto e, muito embora, tenha compreendido o ato deles como uma gentileza que tentavam prestar a mim, em meu peito exultava a compreensão dessa tentativa como uma gentil troca de gratidão. E prosseguimos. Muito havia pela frente, muito a explorar em entendimento. Os fenômenos haveriam de ser, por mim, explicados. Vi que limitar a entrada do indesejado, para os guardadores da "ordem", soava para além da proteção do patrimônio. Eu os entendia e tentava fazer uma leitura dessa cena que remetia às relações históricas, onde a falta de uma sociabilidade se destacava na fragilidade dos semelhantes a si. Esse ato simbólico desprezava o sentimento daquelas crianças, a entrada dos meninos significava para esses mesmos iguais, os riscos de manutenção dos seus empregos. E pensei: tantos outros meninos haveriam em suas casas... em suas comunidades de opressões e abusos. Prossegui na tentativa de entender o porquê de considerar os tantos meninos da fome e da falta descabida, numa categoria de desconsideráveis sentimentos. Foi o que vi em quase todos que ali estavam a passear com suas outras crianças, diferentes do quarteto, as crianças em dedos entrelaçados aos pais tiveram a sorte de nascerem em lares com berços, abraços, carinhos e beijos. Filhos protegidos que quando, ainda nem voz tinham, já eram plenamente ouvidos e vividos na sua condição de sujeitos. Esses pais atentos aos seus filhos, emprestavam aos meninos um ar de rejeição e estranhamento deles estarem desfrutando, como os seus, daquele espaço. Isso me fez indagar as quantas vezes essas crianças tiveram que sobreviver aos olhares de desprezo, enjeitamento, indiferença e sentimento de nojo e repulsa. A leitura do medo, sempre presente no soslaio dos olhares, foi o que eles mais experimentaram. Ainda assim se fortaleciam no riso e na viração existente entre eles, tinham a sede de aprender e de serem tratados como de fato são, apenas gente. Mas não, eram meninos da rua, das bananadas, dos trens e das vielas infestadas. Tinham vontade de nova vida terem no seu existir. Porém a eles a exclusão era dada. Foram olhares de recriminação que vi os frequentadores direcionarem a mim por estar com essas crianças. E vi que apertavam as mãos de seus filhos, cada vez mais forte, quando eles passavam na espontaneidade própria de serem crianças num processo de descobertas. Esses nas feridas emocionais veladas em sorrisos que buscam superar a tristeza, me fizeram ver o quanto fingiam não ver o que a si os olhares mostravam, por eles sofriam, não por sua opção, mas por determinação de terem nascidos nus. Descobertos de lençóis limpos e sem proteção nasciam. Com eles ao meu lado, diferente dos outros que carregavam suas crianças, o vigia me parou, mais uma vez, para advertir-me de minha responsabilidade com os "eminentes perigos", disse-me que se alguma coisa acontecesse, eu responderia. Ah, triste de nós que não sabemos ler além das aparências e a todo momento regulamentamos e protocolamos os efeitos excludentes do capital. O fato foi indicativo de que naqueles meninos era visto o pictograma da pobreza, da violência de nossas ações e de nossa incapacidade de proteger inocentes que poderão se tornar agressivos, como agressivos foram os olhares e os descasos ao tratarem-vos como menos que pessoa, como excrescência de nós. Eram quatro meninos donos da ânsia de conhecerem de perto o que se falava em TVs, redes sociais, noticiários e escolas. Seguimos nosso rumo e eles se ativeram ao gorila dizendo: -"tia, me disseram que o macaco veio da gente, eles são tão parecidos com a gente, não é verdade?" Ao que respondi ser o contrário. A educação humanitária ia se dando.... Ali estava presente a aula de ciências em que criacionismo e evolução foram colocadas a eles em olhos atentos, calaram a fala para guardar o conhecimento. Estavam aprendendo e sabiam o valor dessas descobertas. Ai sim, a autonomia do conhecer começava a ser ativada. Agradeci ao imprevisto e àquela felicidade do momento. A brincadeira e o lúdico eram a exterioridade de sentimentos mais presentes. E "sacaneando" um ao outro diziam: - "Vic é o bicho preguiça $k k k k(. .$.$) , o Nael é o pavão rsrs, e quem vai ser o veado? "Riram muito entre si com essa$ observação, entretanto mais um papo elucidativo sobre sexualidade e gênero ali foi feito. Território espontâneo de explicações ali se fez. Busquei não desperdiçar as deixas propícias ao aprendizado, na leveza de ser e sem juízo de valor estabeleci nosso diálogo, realizado como sintoma de uma prática educativa que em mim habitava e que se tornara relevante, 
significativa, apropriada e vivida para aquele instante. E como catalisadora e adepta ao conhecimento que liberta, lembrando o que me ensinou o mestre Paulo Freire e os seus, prossegui. $O$ que mais marcou em mim foram os gestos de repulsão que se davam aos meninos quando esses perguntavam onde estava o leão, hipopótamo, girafa (...). É muito difícil, em tenra idade, experimentar tanta negação do outro a si. Sobreviver a isso de forma incólume é ato de heroísmo. Depois do que vimos, que viram ser real os animais que desfilavam nas telas e sobre esses animais aprenderam mais um pouco, paramos para apreciar o local em quietude. Sabiam agora a diferença de um réptil, para um mamífero, de uma ave para um inseto, de um anfíbio para um roedor. Bastou a pergunta do Vic, para que a aula acontecesse. Depois de vermos os tucanos fomos ver o jacaré e ele me perguntou: -Tia, por que o jacaré rasteja, o tucano voa? Respondi a pergunta e expliquei como estava setorizado o zoo, expliquei de forma inteligível o que diferenciava cada animal ali visto. A cultura de que são frutos, começa a desmanchar no ar quando o conhecimento se interpõe para a constante transformação, porque apesar de estarem numa determinação, podem rompê-la, e quem sabe que o faça no inesperado dessa vida. Os meus pés já não aguentavam mais andar e acompanha-los em suas corridas para tudo ver, conhecer e provar. O zoológico estava fechando. Era hora de ir. Ao sairmos fomos abordados por um propagandista nos dando panfleto de um restaurante para ali fazermos nossa refeição. Já tínhamos lanchado, mas não almoçado. A fome começava a nos abater. $O$ mais velho e mais esperto, tomando a minha frente, tenta negociar o almoço. Imediatamente pergunta ao propagandista se dava para fazer um preço de inteira para mim e de meia para cada um deles, o que de imediato o Lê, o mais quieto e introspectivo, volta -se ao rapaz intercedendo a meu favor: - "cara, cobra somente o da tia e dos "mais grandes", ela tá quebrada, já pagou o zoológico pra gente, deu dinheiro pra o pedalinho (...) pô, faz aí"!!! Diante do apelo dos meninos, o propagandista, buscando no meu olhar o acordo das falas, nos levou até o restaurante e solicitou à dona que nos fizesse esse desconto. O que de pronto ela atendeu, o restaurante estava quase vazio e a comida parecia ser somente nossa. Pegando em meu braço, disseram: "viu tia, conseguimos". Quanto carinho e cuidado vindo deles a mim! Isso quando nem ao menos pedi ou sinalizei algo parecido. Vic e Lê conseguiram o que tentaram. Saltitantes ao sentirem-se os negociadores a favor de quem, naquele dia os protegia com afeição, um sorriso de sucesso e competência ornou seus rostos. Havíamos ali trocado as gentilezas. Entre degustação e sorrisos partilhávamos uma ceia entre iguais, entre amores $e$ verdades! Entre afetos e companheirismo. $O$ retrato da amizade estava ali inscrito. Naquele instante desejávamos o congelamento da cena. E aí na busca de alongar mais esse tempo, começamos a ver as fotos, quando Vic repetia a cada uma: -"ficaram bala". Absorvi esse vocabulário simples e expressivo. Tudo ali era bala, não somente a foto, mas o acontecimento, a articulação e nossas trocas naquele restaurante de esquina, infatigável esquina. E a tarde ainda não tinha terminado, assim com meus meninos, prossegui o caminho que em breve se desfaria em despedidas. E não queríamos! Na confluência de nossas falas e papos, os pedalinhos e trenzinhos, estavam ainda para serem experimentados. Esses últimos passeios finalizariam, vitoriosamente, esse rico encontro. E refleti, além do mundo da ciência, fizeram parte desse dia, a amizade e a sorte do imprevisto, solo fecundo para brotar o conhecimento, a ternura e o laço. Entendi mais amiúde Rachel de Queiroz no seu poema "Menino Pequeno". Quantas sensações senti, quantas me aguardavam e quantas ainda habitarei. Lembrei de Amado no seu imortal "Capitães da areia". Eu tinha todos os meninos da literatura a passear por mim em pele, osso e pouca carne. Em canelas finas e russas, sandálias de dedos surradas, bermudas tactel, desfilavam sua adversidade e abandono. Tal qual Pedro Bala, Vic, por ser o maior, mais velho e safo, era o líder do quarteto. O Lê era o Professor, concentrado na vida e observador das coisas; o Gato era o Lu, rápido e certeiro, carinhoso e interesseiro. Pirulito era o Nael cheio de desejo e opinião e dizia na lata, na expertise dócil e crua de sua infância o que queria. Esses meninos conheciam todos os códigos de suas mazelas geográficas e políticas. Esses que em suas vidas os permitiam transitar e sobreviver e que, no entanto, também os colocavam, o tempo inteiro, no limite da não aceitação e de cara para os estigmas. 
Desfrutaram o hoje na tentativa de serem plenamente crianças e não mais um símbolo de suas condições vulneráveis de menores pobres, miseráveis e, potencialmente, violentos. Não havia perigo no afeto!! Constatei isso em número, gênero e grau. A característica de cada um ficou retida em mim e gritou em evidência. Em somente um passeio os conhecia através de toda uma obra lida, de todas cenas vividas. Havia ali um intelectual, um calado, um rápido e outro extremamente esperto, e esses se imbricavam na tentativa de uma sobrevivência que os permitisse, ainda que com todos os percalços que apontem um não, o viver do resto de suas inocências. A quem a eles se torna afável a gratidão é feita, e assim dizem: -"pô cara, dá moral pra a tia porque ela dá moral pra gente". - "Tia com outro eu não tiro foto, mas contigo tiro todas". Se isso não for início de laço de amor, não sei mais o que o possa ser. Nos aproximávamos pela sede do saber, pela partilha do viver, por reconhecermo-nos um no outro, por haver respeito e proteção, por sabermo-nos tão vulneráveis e prestes ao erro.... Havia mais em mim neles do que eu pudesse imaginar. E havia eles em mim, numa legitimidade única de quem experimentou o avesso dos desejos. Eles levantaram tantas teorias e teses durante nosso inimaginável encontro, e estas vieram incorporadas de realidades $e$ de um ar despretensiosamente leve, que me surpreendeu na maturidade da análise. De onde vinha tanto saber? Tanta explicação didática e fluida de seu fato, de seu território de violência? Vinha da observação da vida, do empírico, da vivência em si, de se saber impregnado de sua realidade, como dizia, novamente Freire. Apresentavam os códigos da favela, explicavam as facções e diziam ao explicar a organização do crime - "tudo é bandido, só muda as facções"... Falavam dos alemães... - "Cada favela tem um dono de uma facção, que quer tomar a outra se essa vende muito mais bagulhos". - Se os alemães passam, eles cortam a cabeça'. - "Tia, quando entrar na favela toma cuidado, não faz sinal. Lá em Olavo Bilac, onde moro é terrivel". Ao perguntar a eles os aspectos regionais, sociais e culturais de suas vidas, eles me indagaram porque eu queria saber muito. Essa ação me sinalizou um sentido de resguardo do seu saber. É aí que eles se reconhecem e avaliam sua situação, se veem, ainda que não saibam, mas se intuem e percebem-se num mundo de opressão do qual precisam se cuidar para sobreviver. E o olhar da curiosidade alheia os coloca em situação de perigo e instabilidade, o que se traduz em insegurança e dúvida geradas. Todavia prosseguem: - "Tia, todo mundo da comunidade sabe os sinais, até os coroinhas que quase não andam sabem tudo. Tem que ficar esperto". Suas falas são representativas de uma prática comunitária em que está à flor da pele as emoções. $E$ assim dizem: "A gente estuda, mas quase nunca tem aula, quando tem a tia fica sempre com dor de cabeça". E sobre eles respondem: -"A gente se conheceu na rua vendendo doce. Nós éramos inimigos.... e hoje a gente é amigo e a gente veio aqui para tentar arrumar dinheiro para comprar doce, arrumar dinheiro novamente vendendo o doce pra poder depois levar pra casa". E prosseguiam: - "Eu tenho 9 irmãos e tenho que ajudar, em casa o bicho pega"(...) Não gostavam muito de falar de suas vidas, havia sempre uma certa desconfiança a pairar no ar, mas se colocavam e se expressavam em preocupação para que não fossem associados ao estigma da miséria e da violência que os remetiam aos bandidos, dessa forma Vic fala: -"Tia, eu prefiro ser jogador do que ser bandido; bandido morre cedo porque chega a polícia e powww, mata e jogador não, ele ganha muito dinheiro. A gente não pode entrar na vida errada". Eles percebem a sua realidade porque nela veem refletidas as ações, entretanto a visão crítica ainda não é formada, mas o pode e deve ser! Recheados de suas observações me perguntam: - "Tia a senhora é da macumba?" Na tranquilidade digo não e quero saber o porquê da pergunta, o que logo respondem: -" o pessoal do centro onde moro, lá em Caxias, é que é legal assim com a gente. Até parece que a senhora é de lá". Fiquei a pensar o quanto de exterioridade carrega o signo de cada fé e religiosidade. O quanto imprimimos de memória e associações. Porém logo vi que também associaram à fé os colares de miçangas, bem características dessa espiritualidade, que envolvia meu colo. Estava ali explicada a cena pelo ato e pela cenografia. Associamos à nossa vivência tudo o que nos ocorre. Aquele episódio foi ilustrativo desse fato. Símbolos, significados e expressões, os nossos capitães da areia os conheciam. E nessa deixa mostram que vão formando a consciência de si e do que seja o outro. 
Começava a chegar ao fim a nossa aventura de conhecimento, lazer e cultura na Quinta. Nos despedimos. Parto em direção ao trenzinho que me levaria para o portão de entrada e eles se encaminham para o pedalinho, atividade que faltava para completar o dia. Eu não tinha mais corpo e pés para isso. Quando passo por eles, que em dois pedalinhos se dividiram, aceno e, ao me verem, de tamanha felicidade quase se jogaram na água ao mandarem abraços em gestos apertados e lançarem milhões de beijos. Esse fato marcará aquele belo final de tarde, aquele estruturador anoitecer, aquela revigorante e afável tarde de primavera na Quinta. O trenzinho prossegue e eu carrego, agora pelo curto trajeto, a sensação vívida de ter sido feliz. Eles nos pedalinhos, rogo que busquem na vida os entroncamentos para que saiam das pistas em que preconceitos habitam. Rogo que busquem confluências que os tornem iguais, como de fato o são. Verão que além do mundo da ciência, que se fez mais presente em parte desse dia, há impulsões e sentidos outros que o reconhecem como pessoas e sujeitos. Observarão que os códigos de suas geografias e políticas salientam o modo das existências e estes devem ser plenamente decifráveis. Em mim, uma memória vem em presente, a do Thomas, o poeta do filme "O ponto de mutação". Estava ali expressa a sensibilidade e a reflexão num dia único de conversas e trocas. Na cena dos meninos ao se levantarem para acenarem à mim, despedida que traz o político dilema da vida, a causa social, e Neruda me fala: "talvez não ser, é ser sem que tu sejas, sem que vás cortando o meio dia com uma flor azul. Sem que caminhes mais tarde pela névoa e pelos tijolos. Sem essa luz que levas na mão que, talvez, outros não verão dourada, que talvez ninguém soube que crescia como a origem vermelha da rosa. Sem que sejas, enfim, sem que viesses brusca, incitante conhecer a minha vida, rajada de roseira, trigo do vento. E desde então, sou porque tu és. E desde então és sou e somos... E por amor, Serei... Serás...Seremos..."

E me despeço, pensando novamente no poema de Rachel. Ao atravessar aquele muro que me separou do sonho e da realidade, sigo a me perguntar parodiando a poeta: - "Para onde iriam aqueles meninos? .... Ah, quem pode dizer neste país quanto durará aqueles meninos?" E parti na minha solidão dolorida, acionando ogatilho de pensar o"agora em mim" de deixá-los ali.

\section{ANÁLISE, RESULTADOS E DISCUSSÕES}

O relato nos leva a pensar muitas questões que perpassam o sentido da educação informal e da humanização dessa. Nele foi colocada a possibilidade de uma educação ativa para sujeitos sociais que se localizam no limite da exclusão, trazendo elementos de socialização, que buscam capacitar esses sujeitos na sua cidadania e para a compreensão mais afinada da realidade. Elemento que busca estimular o sentimento de pertencimento, acionando o território educacional e a formação profissional docente como caminho a ser traçado. Ainda que esses objetivos não estejam dados a priori, eles se constroem no processo interativo da relação apresentada e que gerou um procedimento educativo cuja cena de troca de saberes aconteceu em lugares distintos.

Vimos acontecer um modo de educar que buscou mais alteridade e laço afetivodos seus participantes. A construção de relações sociais baseadas em princípios de igualdade e justiça social estava presente durante a tarde em que se deu o relato. A 
formação inicial no mundo da ciência, bem como o contato sociocultural deram início a educação informal. Todavia, os atributos de cada uma das experiências educativas se consolidarão no exercício do tempo, na continuidade do ato educativo em local específico para a materialização desse saber.

O relato expôs a educação informal de maneira humanizada e narrou a importância das trocas de conhecimentos, trazidas como elemento de composição do ensino, posto em realidade e na soberania do momento. Mostrou que a EI também atua no campo das emoções e sentimentos, nas correspondências sensíveis e imperceptíveis de uma ação. Em sua característica trabalhou em sintonia a forma da cultura e da política de um grupo, assinalando os laços de pertencimento dos sujeitos que participaram dessa experiência. Outro fato apresentado no relato que envolve e remete à configuração da educação informal foi a análise da construção da identidade coletiva desse pequeno grupo ao refletir os valores e fazeres de sua comunidade. Essa apontou para o desenvolvimento de uma autoestima que cria um capital social na identificação de interesses comuns e no processo de construção de uma cidadania pública que garanta e propicie a existência.

Dessa forma, o relato, caracterizado, em sua análise, dentro da educação informal, mostrou o aprendizado acontecido no respeito mútuo das diferentes culturas, reconhecimento dos sujeitos e do papel do outro, no pleno exercício da empatia e nas explicações do que seja a ética no convívio profissional.

Ainda que haja profunda necessidade de maior contexto e definição das funções e objetivos da EI, a experiência apontou para uma prática de tornar mais afável o ensino que transcende cenários na propositiva de uma educação de largo espectro, colorida, prazerosa, gentil e que se faz no afeto, não prescindindo de uma sistematização das metodologias utilizadas no trabalho cotidiano, ou mesmo de uma análise do trabalho realizado que pode conduzir à construção de artifícios, possibilitando aprendizados gerados na inspiração da relação dos cidadãos.

A EI acontecida e apresentada no relato nasce da escuta atenta às demandas escolares e das exposições que apontam traços de reestruturação do processo formal de ensino na perspectiva de romper com a ignorância sobre ciências e sobre a cultura de exclusão socioeducacional. 
A realidade descrita está afeta à educação de várias formas, como meio de socialização dos conhecimentos culturais e científicos; como articulação e integração a fim de contribuir para a formação de cidadãos que vivem e partilham o mesmo mundo e como capacidade de alargar a educação no seu sentido de atuação profissional (LIBÂNEO, 2010).

A narrativa apresentada também remete à Carvalho et al (2004), quando assinalam que o conhecimento se revela na necessidade e na busca de abordagem que configurem e deem suporte a inteligência. Dizem, ainda, que o ato de conhecer é natural à existência, o saber é encanto que se dá no conhecer, nas descobertas e no experimentar a vida. O relato passa a ser um demonstrativo desse pensamento. Inda nos autores, e para eles, a aprendizagem provém, também de um impulso que acontece de forma inesperada, mas que requer umbackground. Neste sentido, salientam que a aprendizagem ocorra de forma correspondente, apropriada e constantemente renovada por novas descobertas, que também se dão e se complementam fora dos espaços escolares, nos espaços não convencionais, 'que servem belamente o ato de educação'. A fala dos autores reafirma a opção metodológica do trabalho, estimula às novas empreitadas, sobretudo quando Carvalhoet al. indicam que a aprendizagem deve ser formada por atividades que ocorrem à margem das escolas, e que reforçavam a aprendizagem e o ensino escolar dando a eles novas ênfases.

Lembrando Gohn (2011) e inspirada nela, podemos inferir que o relato se finca na educação informal situada num processo de dimensões que ampliam a ação do ensino em lugares propícios a ele, como aconteceu no transcorrer do dia entre a professora e sujeitos espontâneos colocados ao saber, quais sejam sujeitos que por via da EI foram colocados frente à aprendizagem política, na leitura dos cenários, de seus dramas e do que sua cultura os tinha formado. Dimensão que lembra a configuração dos direitos que nos alimentam enquanto cidadãos e que proporcionam o reconhecimento das habilidades e inteligências próprias de uma vivência, com apoio ao desenvolvimento de potencialidades que deverão ser refinadas em contextos e conteúdo próprio aos saberes, em locais adequados, na leveza e nas deixas trazidas pelos sujeitos aprendizes. A formação desses espaços fortalece o ato de ensinar, compartilhar compreensões e analisar o que se tem colocado diante do mundo. 
Há também que se pensar no viver comunitário que possibilita, como vimos nos quatro sujeitos da pesquisa, uma leitura de realidades, uma exposição do ponto de vista e um diálogo acerca da concepção do que se passa ao redor deles e os formam. $\mathrm{O}$ decifrar dos códigos de uma cultura, com a propriedade de quem vive na pele percalços e consequências daquilo que não plantou foi o tom, a voz e a raiz apresentada nas interlocuções apresentadas no relato.

Por fim, cabe assinalar que o ensino de ciências pode acontecer no oportuno, no inesperado, nos muitos espaços de vivências e, conforme Marandino et al (2011), nesse acontecimento é foi de fundamental importância reconstruir os laços para que fosse feita uma reflexão sobre o papel das ciências e de sua articulação com outros espaços educacionais, oportunizando à população, acesso à cultura científica, como se refere a área das ciências biológicas que abrange e interliga-se a outros saberes, conectando as especificidades numa maior compreensão. A biologia, a geografia, a matemática e a história foram fios condutores do pensamento, da prática e dos liames que aproximaram pesquisadora e sujeitos. As falas dos autores repercutiram nesse dia, ou seja: "os conhecimentos das ciências biológicas estavam em nosso cotidiano". Experenciamos isso!

Em Chassot (2000), a interpretativa que nos vestiu foi a de cidadania, inclusão e alfabetização científica. Nessa tríade o relato ganhou tom e faz perceber, que para a docência ser exercida plenamente os sujeitos do conhecimento devem resgatar e o sentido de suas existências. Aos educadores há o desafio de fazerem essa educação científica que requer dedicação e aprimoramento de olhar. A prática profissional deve dar prioridade à formação de cidadãos capazes de participar, em sociedade, dos aspectos e saberes democráticos que incrementam novas convivências, formas e desenhos na arquitetura das vidas.

Ensinar e aprender ciência envolveuvários fatores, abordagens e fontes. Os meninos foram motores de arranque para as explicações que se davam ao calor dos questionamentos e curiosidades. Para frisar esse fato, Marandino (2011), nos auxilia a interpretar e descrever experiências de ensino, trazendo para o campo da análise fatos representativos, sobretudo quando afirma que a educação em museus de ciências naturais, asseguram vivência, deleite e diversão no campo social, educacional e cultural. Vimos isso acontecer nessa tarde de eventual encontro, em que a cultura e a ciência se 
deram mais vastamente, possibilitando a socialização dos saberes dados entre sujeitos, espaços e afetos. Foram recontextualizadas as temáticas mais complexas, e feitas no concreto de uma ação sentida em vida. O aprendizado se tornou mais imaginativo, prazeroso e rico de improvisações específicas ao conhecimento.

Portanto, temos em resultado, uma experiência humanizadora na educação informal que assinala a importância para essa ocorrência em diálogos e lógicas cujo objetivo é de alargar as oportunidades de construção do saber.

\section{(IN) CONCLUSÕES E DESAFIOS}

Destaco nessas (in) conclusões o desafio e a dificuldade de estabelecer espaços e definições para a educação informal. Assinalo as limitações que mostram nossas fragilidades no exercício de outras configurações no ato de educar, marcado pela cultura escolar. Destarte, o tema abordado me permitiu pensar, refletir e discutir acerca da diversidade de espaços onde se manifesta a importância dos museus e zoológicos em se transformarem num registro do nosso olhar e de nossa ação educativa. Essa pode acontecer dentro do possível a bem do conhecer.

O que foi realizado, por meio de um relato pessoal, é demonstrativo de um aprendizado, de uma experiência ou vivência trabalhada num plano de emoção e subjetividades de descrição de um encontro, oportunizado pelos espaços não-formais de ensino, que estão presentes nos territórios de construção de saber e revelam as características do contexto social, recriando os diálogos.

Esse relato apontou, também, para ações acontecidas no terreno interdisciplinar que reconfigura o espaço escolar para além dos muros das escolas. Por isso, o trago para essa publicação que trabalha com educação, ciência e tecnologia no sentido de alargar conceitos da educação informal, trazendo um debate que perpassa o ato da formação cidadã.

Como proposta a EI decorre da ciência que pode e deve ser aprendida pelos sujeitos sociais que partilham essa vida. Por ser ativa e complexa e, por fortalecer a construção sócio-histórico-cultural e política é articulação de conhecimento em plano real. Nesse contexto, reafirmo que ela não é sinônimo de escola e sim é sinônimo de vontade e do fazer que nos refaz à superação das agruras impostas por uma 
determinação que massacra, sobretudo aqueles que não nasceram sob a proteção dos engomados cobertores.

Nessa conexa ideia o relato construído, caminha numa observação de que a escola, somente, não é responsável por tudo aquilo que imputamos à ela, que o espectro informal é muito maior e faz parte de maneirapermanente daquilo que vivemos e estabelecemos como educação. A EI é viés modificável de propositivas que nos impulsionam nesse mundo de pilares mil abarcados pela ciência e pela tecnologia.

Após podermos perceber como a educação se coaduna com o ritmo frenético da vida. Nessa perspectiva nos vem mais uma pergunta que devemos colocar em xeque, qual seja, a de uma cultura de inclusão como fenômeno educacional, fator muito rico e que traz em si possibilidades diversas de formação e de integração com o mundo.

O caráter de uma educação que se traduza somente ao espaço da escola é erro que nos limita socialmente aos muros, separando a estrutura física da sociedade em seu entorno. Tal fato furta sujeitos sociais da possibilidade das suas múltiplas vivências e convivências. Ensinamos e aprendemos, também, para além dos muros da escola, para além do que imaginamos e experimentamos. Isso porque o aprendizado é campo, também, do inesperado e a pesquisa nos apontou esse enlevo.

O ensino é ato de responsabilidade e gentilezas que pode nos colocar num cenário de descentralização da educação. É fundamental para que pensemos novos caminhos que se fortalecem em todas a razões que perfazem o caráter emancipatórioe a consciência da ciência, da cultura, da cidade e dos patrimônios por ele representados.

A educação informal, dentro do contexto trabalhado no artigo, trouxe cláusulas pétreas relacionadas à cidadania; aos direitos de liberdade, igualdade e democracia; bem como buscou articular o exercício da cultura ao fazer docente.

Discorrer sobre a EI fez ver, em sentido mais amplo, como os processos de formação educativa trabalham territórios e espaços de visitação na urgência da demanda atual. Por isso, dimensões diferenciadas da educação mostrama centralidade da educação informal e do desenvolvimento de valores que reorientam as práticas sociais para a construção da vida cotidiana, vidaque não prescinde da popularização da ciência, da cultura e da sensibilidade histórica e artística versadas nos diferentes espaços em que 
se localizam os museus e zoológicos da cidade. Por isso, vivências nesse campo se fazem tão fundamentais.

Concluímos que a análise realizada contribuiu àsdiferentes alternativas e aos possíveis desenhos em que a educação informal possa acontecer, no sentido de expandirações no caminho da formação profissional docente.

Registro, por fim, uma homenagem ao Museu Histórico Nacional, palco de tantas pesquisas, exposições, encontros, saberes, informações e formação. Palco de aprendizagem e ensino que formaram várias gerações de cidadãos amantes da ciência, da investigação, das análises, da história e dos diálogos como células indispensáveis ao conhecimento. Ele não jaz, permanece vivo e perpetuado nos nossos registros e memórias, em cada lembrança e relato.

Em respeito ao Museu, em respeito ao que ali foi praticado e em respeito aos tantos cidadãos que ficarão sem o deslumbramento dessas descobertas, finalizo esse artigo no componente mais solidário que em mim possa habitar. E digo: experiência igual nunca havia tido. Experimentei, nesse Museu os livros em vida, a literatura reconstrutora, a ciência renovadora e aprofundei minha formação docente no recheio da humanização revigorante que nos torna iguais. Incomensuravelmente iguais. 


\section{BIBLIOGRAFIA}

CARVAlHO, A. M.P..de. et al. Ensino de Ciências: Unindo a Pesquisa e a Prática. São Paulo: Thomson, 2004.

CHASSOT, A. Alfabetização científica: questões e desafios para a educação. Ijuí, RS: Unijuí, 2000.

FREIRE, P. Pedagogia do oprimido. Rio de Janeiro: Paz e Terra, 2005.

GASPAR, A. A educação formal e a educação informal em ciências. In:

MASSARANI, L.; MOREIRA, I. de C.\& BRITO, F (org.). Ciência e público caminhos da divulgação científica no Brasil. Rio de Janeiro: Editora da UFRJ, p. 171$183,2002$.

GOHN, M.G. Educação não-formal e cultura Política. São Paulo: Cortez, 2011.

JOSSO, M. C. Experiências de Vida e Formação. São Paulo: Editora Cortez, São Paulo 2004.

LIBÂNEO, J. C. Pedagogia e pedagogos pra quê? São Paulo: Cortez, 2010.

MARANDINO, M. Interfaces na relação museu-escola. Caderno Catarinense de Ensino de Física, Florianópolis, v.18, n.1, p.85-100, abr.2011.

MARANDINO, M.; SELLES, S. E.; FERREIRA, M.S. Ensino de Biologia: histórias e práticas em diferentes espaços educativos. São Paulo: Cortez, 2009.

SANTOS, B. S. A crítica da razão indolente: contra o desperdício da experiência. São Paulo: Cortez, 2000.

SANTOS, B. S. (Org.). Democratizar a democracia: os caminhos da democracia participativa. Rio de Janeiro: Civilização Brasileira, 2002. 